\section{Weed Control in Processing Tomato (Lycopersicon esculentum) with Rimsulfuron and Thifensulfuron Applied Alone or with Chlorothalonil or Copper Pesticides}

\author{
Darren E. Robinson and Nader Soltani ${ }^{1}$ \\ University of Guelph, Ridgetown Campus, Ridgetown, ON, Canada NOP 2CO
}

\begin{abstract}
Allan S. Hamill
Agriculture and Agri-Food Canada Agriculture and Agri-Food Canada, Harrow, ON, Canada NOR 1GO
\end{abstract}

Peter H. Sikkema

University of Guelph, Ridgetown Campus, Ridgetown, ON, Canada NOP 2 CO

Additional index words. crop tolerance, Lycopersicon esculentum, metribuzin, postemergence herbicides, rimsulfuron, thifensulfuron-methyl, tomato injury, yield

\begin{abstract}
Combining herbicides and fungicides can improve production efficiency; however, there is little information on the effect of these mixtures on weed control and processing tomato crop response. Six field trials were conducted from 2002 to 2004 in Ontario to study the effect of rimsulfuron and thifensulfuron applied alone or in combination with metribuzin and with or without chlorothalonil or copper fungicides on processing tomato. There was no visual injury or reduction in marketable yield of processing tomato with rimsulfuron or thifensulfuron alone or when tank-mixed with chlorothalonil or copper hydroxide. Rimsulfuron, thifensulfuron, rimsulfuron plus metribuzin, and thifensulfuron plus metribuzin could be tank-mixed with chlorothalonil without a reduction in weed control. However, efficacy of rimsulfuron and thifensulfuron were reduced when tank-mixed with copper hydroxide. The reduction in weed control incited by adding copper hydroxide was overcome with a low rate $\left(150 \mathrm{~g} \cdot \mathrm{ha}^{-1} \mathrm{a}\right.$.i. $)$ of metribuzin for thifensulfuron but not rimsulfuron. Application of rimsulfuron and thifensulfuron alone or with low rates of metribuzin and chlorothalonil could provide tomato growers with a single-pass treatment for the control of troublesome weeds and diseases.
\end{abstract}

Tomato (Lycopersicon esculentum) is grown on approximately 8000 ha in Ontario and has a farm gate value of more than $\$ 72$ million, representing approximately $29 \%$ of the total farm value of field grown vegetable crops in the province (OMAFRA, 2002). Intensive horticultural practices, including effective integrated weed and disease management, are needed for profitable production of this high-value crop.

Broadleaf weed control is one of the most important management considerations in tomato production. Current problem weeds in the region include velvetleaf (Abutilon theophrasti Medic.), redroot pigweed (Amar-

Received for publication 2 Mar. 2006. Accepted for publication 10 Apr. 2006. Funding for this project was provided by the Ontario Tomato Research Institute and the Agriculture and Agri-Food Canada Matching Investment Initiative. We thank Kristen McNaughton and Mac Whaley for their expertise and technical assistance in these studies. ${ }^{1}$ To whom correspondence should be addressed; e-mailnsoltani@ridgetownc.uoguelph.ca. anthus retroflexus L.), and common lambsquarters (Chenopodium album L.). Weed management in tomato consists of a combination of herbicides and interrow cultivation. The only registered postemergent (POST) herbicides for broadleaf weed control in tomato grown in Ontario are metribuzin, rimsufuron, and thifensulfuron (OMAFRA, 2006). Growers generally use metribuzin in combination with rimsulfuron for broaderspectrum weed control. The recent registration of thifensulfuron in tomato has provided tomato growers with an option for triazineresistant common lambsquarters control.

Chlorathalonil (Bravo, Syngenta, Greensboro, N.C.) is a broad-spectrum, contact fungicide that tomato growers often use to control anthracnose (Colletotrichum graminicola), early blight (Alternaria solani), septoria leafspot (Septoria sp.), botrytis blight (Botrytis cinerea), downy mildew (Peronospora antirrhini), and rust (Puccinia malvacearum). Copper hydroxide (Kocide, Griffin, Valdusta, Ga.) is another popular fungicide/ bactericide used in tomato for anthracnose, early blight, and septoria leaf spot control in addition to control of bacterial speck (Pseudomonas syringae), bacterial spot (Xanthomonas campestris), brown spot (Pseudomonas cattleyae), late blight (Phytophthora infestans), and leaf mold (Fulvia fulvum).

Although optimum application timing of these POST herbicides and fungicides often coincides, currently, no combination of herbicides and fungicides are labeled for use in tomato grown in Ontario. Coapplication of POST herbicides with fungicides could allow growers to reduce the number of passes through the field and reduce fuel and labor costs, wear and tear on machinery, soil compaction, as well as mechanical damage to the tomato vine (Jordan et al., 2003, 2006, Lancaster et al., 2005a, 2005b).

There are no published data on the effects of coapplications of chlorothalonil or copper hydroxide with rimsulfuron and thifensulfuron alone or in combination with metribuzin on weed control and tomato crop safety. In addition, information on compatibility of these herbicides with other crop protection products is very important to tomato growers because incompatibility in the tank can result in significant tomato crop and equipment damage as well as reduction in weed and other pest control (Lancaster et al., 2005a). More research is needed to identify herbicide and fungicide tank mixes that provide consistent control of problem weeds and diseases in tomatoe with an adequate margin of crop safety.

The objectives of this research, therefore, were to determine if the addition of a fungicide/bactericide (chlorothalonil or copper hydroxide) to rimsulfuron, thifensulfuron, rimsulfuron plus metribuzin, or thifensulfuron plus metribuzin increased injury to tomato, reduced weed control, and reduced tomato yield.

\section{Materials and Methods}

Field studies were conducted at the Agriculture and Agri-Food Canada Research Center, Harrow, Ontario, and at Ridgetown College, Ridgetown, Ontario, in 2002 to 2004. The soil at Harrow was a Fox sandy loam with $82.5 \%$ sand, $5 \%$ silt, $12.5 \%$ clay, $2.6 \%$ organic matter ( 3 years), and $\mathrm{pH}$ of 6.7 , 6.0 , and 6.0 in 2002, 2003, and 2004, respectively. The soil at Ridgetown was a Brookston loam with $48.7 \%$ sand, $32.1 \%$ silt, $19.2 \%$ clay, $6.0 \%$ organic matter, and $\mathrm{pH}$ of 6.9 in 2002 ; $53.9 \%$ sand, $29.3 \%$ silt, $16.7 \%$ clay, $4.7 \%$ organic matter, and $\mathrm{pH}$ of 7.5 in 2003; and $49.3 \%$ sand, $29.5 \%$ silt, $21.2 \%$ clay, $5.8 \%$ organic matter, and $\mathrm{pH}$ of 5.8 in 2004. Seedbed preparation at both locations consisted of fall moldboard plowing followed by two passes with a field S-tine cultivator with rolling basket harrows in the spring.

Herbicide treatments included rimsulfuron at $15 \mathrm{~g} \cdot \mathrm{ha}^{-1}$ a.i., thifensulfuron at $6 \mathrm{~g} \cdot \mathrm{ha}^{-1}$ a.i. applied alone or in combination with metribuzin at $150 \mathrm{~g} \cdot \mathrm{ha}^{-1}$ a.i. in a $4 \times 3$ factorial arrangement with no fungicide, chlorothalonil at $1.6 \mathrm{~kg} \cdot \mathrm{ha}^{-1}$ a.i., or copper hydroxide at 2.2 $\mathrm{g} \cdot \mathrm{ha}^{-1}$ a.i. for a total of 12 herbicide-fungicide 
treatment combinations. A nontreated control was included for comparison. All treatments except the nontreated control included a nonionic surfactant (Agral 90, Norac Concepts, Inc., Orleans, ON, Canada) at $0.2 \%$ v/v. A randomized complete block arranged in a split-plot experimental design with 4 replications was used. Main plots were $1.5 \mathrm{~m}$ wide $\times 8 \mathrm{~m}$ long and subplots were 1.5 wide $\times 4 \mathrm{~m}$ long. The main plot factors consisted of the herbicide-fungicide treatments and the nontreated control and the subplots were one half was left weedy, whereas the other one half was maintained weed-free through cultivation and hand hoeing. Tomato transplants 'Heinz 9553' were grown in a greenhouse and when approximately 12 to $15 \mathrm{~cm}$ tall (2-3 leaf stage) were transplanted at a depth of 5.0 to $7.5 \mathrm{~cm}$ in twin rows $30 \mathrm{~cm}$ apart at a rate of 30,000 transplants ha ${ }^{-1}$ on 28 May 2002, 5 June 2003, and 2 June 2004, at Harrow and on 7 June 2002, 30 May 2003, and 1 June 2004, at Ridgetown. The trial areas were fertilized according to recommended Ontario crop production practices (OMAFRA, 2001), and rainfall provided adequate moisture each year, so irrigation was not needed.

Treatments were applied approximately $28 \mathrm{~d}$ after transplanting when the tomatoes were in the eight to 10 leaf stage using a $\mathrm{CO}_{2}$ pressurized backpack sprayer calibrated to deliver $200 \mathrm{~L} \cdot \mathrm{ha}^{-1}$ at $200 \mathrm{kPa}$ using 8002 flatfan nozzles (Spraying Systems Co., Wheaton, IL). The boom was $1.0 \mathrm{~m}$ long with three nozzles spaced $50 \mathrm{~cm}$ apart.

Visual crop injury was rated on the weedfree subplots 7, 14, and 28 days after treatment (DAT) on a scale of $0=$ no visible plant injury to $100 \%=$ total plant necrosis. At $28 \mathrm{~d}$ after treatment (DAT), weed densities by species in a $1 \mathrm{~m}^{-2}$ quadrant placed in the middle of each weedy subplot was recorded. Marketable yields were measured at crop maturity by hand harvesting the red fruit in a 2-m length of row from the middle of the weedy and weed-free subplots of each treatment at all locations. At Harrow, tomatoes were harvested on 4 Sept. 2002, 25 Sept. 2003, and 4 Oct. 2004. At Ridgetown, tomatoes were harvested on 17 Sept. 2001, 1 Oct. 2003, and 27 Sept. 2004.

Data were subjected to analysis of variance to determine the effect of location, year, years by location, and treatment interactions on visual injury, weed control, and yield. Because the year by location by treatment interactions were not significant, data were combined over locations and years and analyzed using the PROC MIXED procedure of SAS (1999). Variances were partitioned into the random effects of locations, years, years by locations, blocks within years by locations, and their interactions with fixed effects. Significance of random effects was tested using a Z-test of the variance estimate and fixed effects were tested using F-tests. Error assumptions of the variance analyses (random, homogeneous, normal distribution of error) were confirmed using residual plots and the Shapiro-Wilk normality test. Percent visual injury at 7,14 , and 28 DAT were subjected to square root transformation (Bartlett, 1947), compared on the transformed scale, and converted back to the original scale for presentation of results. Treatment means for visual injury, percent weed control, and tomato yield were separated using orthogonal contrasts $(\alpha=0.05)$.

\section{Results and Discussion}

The herbicide by fungicide interactions were significant for velvetleaf and common lambsquarters control but not for redroot pigweed at 28 DAT (Table 1). Data for each evaluated weed was sorted by herbicide treatment and the effect of the fungicide treatment within each herbicide treatment are shown in Table 1. The addition of chlorothalonil to rimsulfuron or thifensulfuron alone or combined with metribuzin did not reduce control of any weed present at 28 DAT compared with control of those weeds by the herbicide treatments without that fungicide (Table 1). These results are in contrast to those of other researchers who observed a reduction in spurred anoda (Anoda cristata L.) control in peanuts (Arachis hypogaea L.) by lactofen (Jordan et al., 2006) or smooth pigweed (Amaranthus hybridus L.) control by 2,4-DB (Lancaster et al., 2005b) when chlorothalonil was added to the herbicide.

Velvetleaf control at 28 DAT was relatively low for all the herbicide treatments evaluated. Rimsulfuron plus metribuzin was the only herbicide treatment that provided greater than $80 \%$ control (Table 1). The coapplication of the herbicide with the fungicide, chlorothalonil, did not reduce velvetleaf control. The coapplication of thifensulfuron or rimsulfuron plus metribuzin with copper hydroxide reduced the control of velvetleaf by $34 \%$ and $22 \%$, respectively.

Although redroot pigweed control ranged from $87 \%$ to $100 \%$ at 28 DAT regardless of herbicide and fungicide combination, the addition of copper hydroxide to all treatments except thifensulfuron plus metribuzin numerically reduced control (Table 1).

The addition of copper hydroxide significantly reduced common lambsquarters control by thifensulfuron from $94 \%$ to $79 \%$ (Table 1 ). Common lambsquarters control by rimsulfuron alone, which was only $71 \%$, and by rimsulfuron plus metribuzin or thifensulfuron plus metribuzin, which was $91 \%$ or $96 \%$, respectively, was not reduced significantly with the addition of copper hydroxide, although control was numerically reduced (Table 1).

Velvetleaf and common lambsquarters control were affected more than redroot pigweed control with the coapplication of herbicides and copper hydroxide. This may be because redroot pigweed is very sensitive to rimsulfuron, thifensulfuron, and metribuzin (OMAFRA, 2006). Ackley et al. (1997) reported similar results with rimsulfuron at $35 \mathrm{~g} \cdot \mathrm{ha}^{-1}$ in tomatoe. Rimsulfuron provides excellent control of pigweed and fair control of common lambsquarters and velvetleaf, whereas thifensulfuron provides excellent control of pigweed and common lambsquarters and good control of velvetleaf (OMAFRA, 2006). Other reasons for differences in control level may include the presence of hairs on the leaf surface of velvetleaf or unevenness of the cuticle covering leaves of lambsquarters that can inhibit uptake/absorption. We also noticed that copper hydroxide did not mix well with the herbicides evaluated, and this may have contributed to the reduction in efficacy of the herbicides.

Visual injury and yield in the weed-free subplots was not significantly greater than the nontreated control in any of the treatment combinations (Table 1). Crop injury symptoms evaluated included slight leaf chlorosis with a copper tint, leaf distortion, and crinkling. The herbicide by fungicide treatment interaction was not significant for tomato crop injury and yield (data not shown). Injury from all treatments at 7 DAT was $0 \%$ to $6 \%$, and the addition of chlorothalonil or copper hydroxide did not increase injury compared

Table 1. Influence of fungicide/bactericide and herbicide ${ }^{\mathrm{z}}$ tank-mix treatments on percent velvetleaf, redroot pigweed, and common lambsquarters control at $28 \mathrm{~d}$ after treatment (DAT) and tomato marketable yield in the weedy trials at Harrow, ON, and Ridgetown, ON, in 2002-2004.,

\begin{tabular}{|c|c|c|c|c|c|c|c|c|c|c|c|c|}
\hline \multirow[b]{2}{*}{ Herbicide } & \multicolumn{3}{|c|}{ Velvetleaf control (\%) } & \multicolumn{3}{|c|}{ Redroot pigweed control (\%) } & \multicolumn{3}{|c|}{ Lambsquarters control (\%) } & \multicolumn{3}{|c|}{ Tomato marketable yield $\left(\mathrm{t} \mathrm{ha}^{-1}\right)$} \\
\hline & None & Chlorothalonil & $\overline{\text { Copper }}$ & None & Chlorothalonil & $\overline{\text { Copper }}$ & None & Chlorothalonil & $\overline{\text { Copper }}$ & None & Chlorothalonil & Copper \\
\hline Rimsulfuron & $58 \mathrm{a}$ & $54 \mathrm{a}$ & $45 \mathrm{a}$ & $95 \mathrm{a}$ & $95 \mathrm{a}$ & $87 \mathrm{a}$ & $71 \mathrm{a}$ & $70 \mathrm{a}$ & $63 \mathrm{a}$ & $45.5 \mathrm{a}$ & $50.1 \mathrm{a}$ & $49.6 \mathrm{a}$ \\
\hline Thifensulfuron & $66 \mathrm{a}$ & $58 \mathrm{a}$ & $32 \mathrm{~b}$ & $100 \mathrm{a}$ & $98 \mathrm{a}$ & $93 \mathrm{a}$ & $94 \mathrm{a}$ & $81 \mathrm{a}$ & $79 \mathrm{~b}$ & $79.1 \mathrm{a}$ & $62.3 \mathrm{a}$ & $38.5 \mathrm{~b}$ \\
\hline Rimsulfuron + metribuzin & $82 \mathrm{a}$ & $76 \mathrm{a}$ & $60 \mathrm{~b}$ & $98 \mathrm{a}$ & $92 \mathrm{a}$ & $91 \mathrm{a}$ & $91 \mathrm{a}$ & $89 \mathrm{a}$ & $88 \mathrm{a}$ & $76.0 \mathrm{a}$ & $81.9 \mathrm{a}$ & $47.9 \mathrm{~b}$ \\
\hline Thifensulfuron + metribuzin & $65 \mathrm{a}$ & $73 \mathrm{a}$ & $59 \mathrm{a}$ & $92 \mathrm{a}$ & $96 \mathrm{a}$ & $92 \mathrm{a}$ & $96 \mathrm{a}$ & $95 \mathrm{a}$ & $88 \mathrm{a}$ & $78.6 \mathrm{a}$ & $82.1 \mathrm{a}$ & $72.7 \mathrm{a}$ \\
\hline
\end{tabular}

${ }^{\mathrm{z}}$ Herbicide treatments included $0.2 \% \mathrm{v} / \mathrm{v}$ nonionic surfactant.

${ }^{\mathrm{y}}$ Means followed by different letters within a row (separated for each weed species and yields) are significantly different from one another according to orthogonal contrasts $(\alpha=0.05)$.

${ }^{\mathrm{x}}$ Mean weed density for velvetleaf, redroot pigweed, and lambsquarters for all sites combined were 7,33 , and $16 \mathrm{~m}^{-2}$, respectively; marketable yield in the nontreated, weed-free control was $78.8 \mathrm{t} \cdot \mathrm{ha}^{-1}$, and marketable yield in the nontreated, weedy control was $37.6 \mathrm{t} \cdot \mathrm{ha} \mathrm{a}^{-1}$. 
with injury from those herbicide treatments without the fungicides (data not shown). Tomato plants outgrew the visual injury by 28 DAT (data not shown). The relatively low level of crop injury observed in this study with thifensulfuron of $3 \%$ or less is similar to that in previous research on 12 varieties of processing tomatoes (Soltani et al., 2005). Ackley et al. (1997) and Wilson et al. (2001) also observed similar low levels of tomato crop injury from rimsulfuron as in this study.

The herbicide by fungicide interaction was not significant for yields in the weedfree subplots, and the relatively low injury levels at 7, 14, and 28 DAT seemingly had no effect on tomato yields because there were no significant differences among treatments with yields ranging from 78.7 to $88.4 \mathrm{t} \cdot \mathrm{ha}^{-1}$ (data not shown). Weed-free treatment yields also were not different from the nontreated, weed-free yield of $78.8 \mathrm{t} \cdot \mathrm{ha}^{-1}$ according to single df contrasts (data not shown).

The herbicide by fungicide treatment interaction was significant for yields in subplots that were not hand-weeded so data were sorted by herbicide treatment and the effect of the fungicide treatment on tomato yield within each herbicide treatment are shown in Table 1. As would be expected because rimsulfuron alone did not provide effective velvetleaf or common lambsquarters control, yields with this herbicide treatment were only 45.5 to $50.1 \mathrm{t} \cdot \mathrm{ha}^{-1}$ and the addition of either fungicide did not affect yields significantly (Table 1). However, yields with rimsulfuron plus metribuzin were reduced from 76.0 to $47.9 \mathrm{t} \cdot \mathrm{ha}^{-1}$ when copper hydroxide was included in the application, reflecting the significant reduction in velvetleaf control as well as the numeric reduction in redroot pigweed and common lambsquarters control by the latter combination. Similarly, thifensulfron yields were reduced from 79.1 to $38.5 \mathrm{t} \cdot \mathrm{ha}^{-1}$ when copper hydroxide was included in the application most likely as a result of the significant reduction in both velvetleaf and common lambsquarters control and the numeric reduction in redroot pigweed control incited by that herbicide and fungicide combination. Thifensulfuron plus metribuzin yields were similar with and without fungicides, although the addition of copper hydroxide numerically reduced the yield (Table 1), suggesting that perhaps the addition of metribuzin to thifensulfuron provided enough improvement in weed control to overcome the negative impact of adding copper hydroxide to thifensulfuron alone.

Overall, none of the herbicide treatments used in this study provided greater than $82 \%$ velvetleaf control, and other options for control of this weed in processing tomato should be used. In addition, rimsulfuron alone did not provide more than $71 \%$ common lambsquarters control in this study and should only be applied in combination with an effective common lambsquarters herbicide. Based on the herbicide by fungicide treatment interaction results, POST applications of rimsulfuron or thifensulfuron alone or plus a low rate of metribuzin at $150 \mathrm{~g} \cdot \mathrm{ha}^{-1}$ can be combined with chlorothalonil without reducing velvetleaf, redroot pigweed, or common lambsquarters control and without risk of increased injury or yield reductions in processing tomato. Copper hydroxide, however, should not be tank-mixed with rimsulfuron or thifensulfuron alone or with rimsulfuron plus metribuzin, because it may reduce the efficacy of these herbicides resulting in reduced tomato yields. The addition of the low rate of metribuzin to thifensulfuron overcame the reduction in weed control and subsequent loss of tomato yield observed when copper hydroxide was added to thifensulfuron alone and may be a viable treatment if coapplication of herbicides and a fungicide is desired. This combination and the chlorothalonil combinations could provide tomato growers an integrated option that will increase the spectrum of pest control and crop production efficiency without sacrificing control of evaluated troublesome broadleaf weeds.

\section{Literature Cited}

Ackley, J.A., H.P. Wilson, and T.E. Hines. 1997. Rimsulfuron and metribuzin efficacy in trans- planted tomato (Lycopersicum esculentus). Weed Technol. 11:324-328.

Bartlett, M.S. 1947. The use of transformations. Biometrics 3:39-52.

Jordan, D.L., A.S. Culpepper, W.J. Grichar, J. Tredaway-Ducar, B.J. Brecke, and A.C. York. 2003. Weed control with combinations of selected fungicides and herbicides applied postemergence to peanut (Arachis hypogaea L.). Peanut Sci. 30:1-8.

Jordan, D.L., D. Johnson, and A.C. York. 2006 Influence of foliar fertilizers and pesticides on efficacy of selected postemergence herbicides. Weed Sci. Soc. Amer. Abstr. 46:38.

Lancaster, S.H., D.L. Jordan, R.L. Brandenburg, B. Royal, B. Shew, J. Bailey, V. Curtis, A.C. York, J.W. Wilcut, J. Beam, E. Prostko, A.S. Culpepper, T. Grey, C. Johnson III, R. Kemerait, B. Brecke, G. McDonald, J. Tredaway-Ducar, B. College, and B. Wall. 2005a. Tank mixing chemicals applied to peanut crops: are the chemicals compatible? Extension Bulletin no. AGW653. North Carolina Cooperative Extension Service, NC. $11 \mathrm{pp}$.

Lancaster, S.H., D.L. Jordan, J.F. Spears, A.C. York, J.W. Wilcut, D.W. Monks, R.B. Batts, and R.L. Brandenburg. 2005b. Sicklepod (Senna obtusifolia) control and seed production after 2,4-DB applied alone and with fungicides or insecticides. Weed Technol. 19:451-455.

Ontario Ministry of Agriculture, Food, and Rural Affairs (OMAFRA). 2001. Vegetable Production Recommendations. Publication 363. Toronto, ON: Ontario Ministry of Agriculture, Food, and Rural Affairs.

Ontario Ministry of Agriculture, Food, and Rural Affairs (OMAFRA). 2002. Farm values of commercial fruit and vegetable crops. Available at: http://www.gov.on.ca/OMAFRA/english/stats/ hort/index.html. Accessed Feb. 24, 2006.

Ontario Ministry of Agriculture, Food, and Rural Affairs (OMAFRA). 2006. Guide to Weed Control. Publication 75. Toronto, ON: Ontario Ministry of Agriculture, Food, and Rural Affairs.

Soltani, N., D.E. Robinson, A.S. Hamill, S. Bowley, and P.H. Sikkema. 2005. Tolerance of processing tomato (Lycopersicon esculentum) to thifensulfuron-methyl. Weed Technol. 19:669-673.

Wilson, H.P., D.W. Monks, T.E. Hines, and R.J. Mills. 2001. Responses of potato (Solanum tuberosum), tomato (Lycopersicon esculentum), and several weeds to ASC-67040 herbicide. Weed Technol. 15:271-276. 